\title{
A Study on the Practice of Witch-Hunting in Assam, an Ontology
}

\author{
Devina Neogi
}

\author{
Ramaiah Public Policy Center, India
}

\begin{abstract}
Witch-Hunting is a gender-based violence which undermines women dignity and violates women right to lives. This research paper studies the witch beliefs and witch hunts practices that exist in the state of Assam. The study investigates the reasons behind the existence of such beliefs and practices. It also tries to locate the inter-linkages between witch beliefs and witch hunt at the same time. Also, the reason for witch-hunting can be actual and speculative. It tries to understand the benefits that people get from sustaining these beliefs and practices. In this paper, I propose an ontological framework of witch-hunting that provides a structured logic for policy intervention by streamlining the different perspective of tackling this problem. The ontology provides us a lens to captures the nature of the people in Assam where witch beliefs and witchcraft continue to exists, the common witch beliefs and its relationship with the witch-hunting practices; it examines the interconnections between mythological tales and the real scenario of witch beliefs and witch hunt, its association with violence, and anti-witch hunt awareness and sensitization. The ontology provides a systematic, systemic and symmetric approach to viewing the problem which also help us to understand the limitation of the problem of witch-hunting.
\end{abstract}

Keywords: Witch-hunting, Assam, Practice, Women, Rights, Safety

\section{Introduction}

Gender violence has been a disturbing phenomenon since time and over. The most prevalent form of genderbased violence prevails against women. Physical, mental and psychological violence against women are term as gender-based violence (WHO, 2017). The violence against women takes place in epidemic proportions in many countries around the world. Violence against women is a gross violation of women's rights which has serious health impacts and is also costly to economic development (Shakti, 2017). According to WHO from 1997 to 2005 many girls and adolescents are forced into initiation in several countries (WHO, 2013). This has an overall impact on the economy by reducing women's labor participation and productivity thus resulting in lower earnings, savings, and investment (McCoy, 2014).

The act of violence against women has been classified as control, emotional violence, physical violence, and sexual violence (Krantz \& Garcia-Moreno, 2005). In South Asia, violence against women is a particularly relevant issue, which is also known to be 'the most gender insensitive region in the world'(Niaz, 2003). Women in countries like India suffer from and are exploited in various ways: domestic violence, battering, rape, marital rape, incest, dowry-related violence, female infanticide, sexual harassment, human trafficking for prostitution and, last but not the least, witch-hunting (Yogesh \& Kosambi, 1993). In recent years, the media has reported many cases of witch-hunting incidents in the country and most of the reporting came from a state called Assam. Witch-Hunting is gender-based violence that mostly targets women from a lower class and elderly women, women living alone, single and owning property are targeted on the basis of the belief that they are practicing black magic to harm an individual, group of people or a community (Mahanta, 2017).

\section{Rationale}

The rationale of my study is that Witch-Hunting as an academic genre has not been explored extensively by scholars and academics. Why the ratio of women is targeted in Witch-Hunt is more? This practice has neither 
spared men, children nor women. But women are the primary target of witch-hunting (PLD, 2013). Therefore it is called witch-Hunting and not wizard hunting. The tradition of persecuting women on the grounds of practicing black magic has been as old as belief in witchcraft itself. But off late targeting and killing on the grounds of witch-hunt has been increased. It is more alarming as women belonging from lower strata of the society like Dalit or tribal communities are being targeted. And the reasons for such perpetrating are mostly property-based, gendered-based, and political-based (Bever, 2002). There are several reasons for the witch hunt practice: greed for the property, depriving women of traditional property rights is a side-lined fact, illiteracy, poor educational levels, and superstitious beliefs (Behera, 2015). Lack of sufficient health care also leaves people with no other option but dependency on superstition. One of the root causes is the patriarchal system. Men use weapons such as witch-hunting to get rid of women they fear. Certain socio-economic factors like land-grabbing, property disputes, personal rivalry, and resistance to sexual advances also play an important role (Sadual, 2015). The perpetrators are often neighbors as well as their own family members. For example, an aging woman may be called a witch by her stepson as she has most of the assets in her name. Also, there are instances where the land grabbers brides' men with money or liquor to get rid of women they fear or hate by name calling her like witch or daini. There exist a local Ojha (witch doctor) who takes bribes to identify a witch. It stands important to situate the caste and class dynamics that play a central role in this regard. Identifying Dalit or Adivasi women as witches helps to preserve the upper caste/class hegemony (Iqbal, 2015).

The term "witch" is utilized in a setting, where a woman is identified as an evil creature that is supposedly practicing black magic intending to harm society. The rural or tribal society terms such women as "DAINI" (Medhi, 2016)

\section{Situating Witch-Hunting in the context of Scapegoating}

The concept of scapegoat theory in the context of witch hunt and violence against women can be explained through the theory of dual deviance (Chaudhuri, 2012). A deviant group (the accused and family) on one side and the moral entrepreneurs (the accuser/labeling) group on the other. The deviant group is considered to be a threat to the moral order of society. In this case, the deviant and labeling group belongs to the same community. The labeling group (moral entrepreneurs) consists of rule creators and rule enforcers who are dominated by the upper strata of the society. They maintain moral boundaries; they also have power and public support at their disposal. Now, this is the first level of deviance and this followed by what is called the second level of deviance whereby the moral entrepreneurs (the labeling group) are perceived as deviant by the third group of people from outside the community and this third group act as moral entrepreneurs in the second level. This group consists of the legal authorities or the police specifically. At this level, witch hunt is seen as a phenomenon harmful for the tribal society and accused as innocent. There is by any account are no "genuine" purpose behind a trial, an investigation, or an examination, we have been persuaded that these were directed for different thought processes and motives. The prior totalitarian scholars centered upon witch-hunting as methods where political elites could maintain their status and power, intimidating possibly enemies, and balance out on all the aspects in their social life. While real witch-hunt infrequently happens in the cutting-edge period, there is a general logical conviction that black magic is mythological, and thus it is not wrongdoing or a crime that can be committed.

\section{Physical and Social Consequences}

The consequences of witch-hunting can be extremely severe and fatal. But the two most common consequences of witch-hunting are immediate and longstanding. (Mehra \& Agrawal, 2016). The immediate form of consequences is when the victim is called by names, along with verbal abuse and physical violence. Even police records suggest that violence associated with witch-hunting is often gendered and sexual in nature. The physical violence occurs where the perpetrators enter into the victims' house with force followed by humiliation, blackening of face, breaking of teeth, and forced consumption of dirty water. Physical violence is explicit in nature and it can be extremely fatal when occurs. (PLD, 2013). The longstanding or long-term consequences are psychological which are discreet in nature. Social deprivation and ostracism are the most prevalent forms of 
longstanding consequences. The victim can be exiled from her village or communities or denied her basic right to live. The victim may suffer silently (Mehra \& Agrawal, 2016).

There is still deficiency and inadequacy in mitigating the problem of witch-hunting. As this research finds traditional along with perpetrators (individual and communities) selfish interest have been a major hurdle in expelling the threat from society. This paper has taken the state of Assam to give an account on the practice of witchcraft and witch-hunting although it may have different forms with a variety of areas. Assam is a northeastern state of India and is home to various tribes. In the interiors of Assam, tribal people hold strong beliefs in mythical stories and superstitions. This paper is based on the qualitative study and anecdotal evidence on the most affected gender.

\section{Objectives}

- To systematically review the manifestation and prevalence of witch-hunt prejudice among women in Assam

- To study the reasons for the perpetuation of such practices

- To identify and reveal the common belief around witch-hunt in Assam

\section{Method}

The latest articles on witch-hunting in Assam dates till 2017. A thorough Scopus and Google Scholar search was conducted using the search string: [Tittle/Abstract] OR "Witch-Hunt" [TITTLE/ABSTRACT] OR "WITCH"'HUNT"'"WOMEN" [TITTLE/ABSTRACT]. This is called the Boolean search (Beal, 2020). Total of 24,000 paper were available on witch-hunting in India context and 520 research paper were available in Assam context. The ontology of Witch-Hunting in Assam was formed after reviewing the 520-research paper.

The prejudicial act of witch-hunting can be better understood with a systematic and symmetric ontology. The ontology is the theory of construct. The ontology of witch-hunting in Assam defines the problem's dimensions, elements, and boundaries (Ramaprasad \& Syn, 2015). It deconstructs the problem's complexity hierarchically (Simon, 1962), visualizes it in structured natural-English, and encapsulates its combinatorial logic (Cimino, 2006). It organizes the terminologies, taxonomies, and narratives of the problem systemically, systematically, and symmetrically (Cameron et al., 2017; Chandrasekaran et al., 1999; Cimino, 2006; Gruber, 1995, 2008). It is a cognitive map (Ramaprasad, 1987; Ramaprasad \& Mitroff, 1984; Ramaprasad \& Poon, 1985) to (a) understand the problem, (b) determine effective, ineffective, and absent guidelines, and (c) suggest policy implementation to curb the problem (Ramaprasad, 1982, 1983). The dimensions of the ontology have been formulated based on extensive literature review.

The Act dimension enumerates physical, social, and psychological acts. The factor dimension lists the possible factors- revenge, sexual orientation, property, land rights, chauvinism, patriarchy, and scapegoating. The perpetrators can be individuals, families, and communities. The acts of witch-hunting have 63 potential pathways by concatenating the elements in Factors and Perpetrators with interleaved phrases. Examples include (a) scapegoating based physical violence by families, (b) chauvinism based social violence by the individual, and (c) patriarchy based psychological violence by communities. The perpetrators perpetrate on sex, income, caste, and occupation of the victims. The impact (left-most dimension) could be social, economic, moral, and psychological. Together with 63 acts of prejudice, the ontology encapsulates 1008 pathways. 
A Study on the practice of Witch-Hunting in Assam

\begin{tabular}{|c|c|c|c|c|c|c|c|c|c|}
\hline Impact & & Factor & & Act & & Perpetrators & & Perpetrated & \\
\hline Social & $\overline{0}$ & Revenge & च & Physical & 뭉 & Individual & 五 & Sex & $\overline{\tilde{n}}$ \\
\hline Economical & 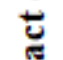 & Sexual Orientation & $\stackrel{\Sigma}{\tilde{n}}$ & Psychological & 气 & Families & 으 & Income & 光 \\
\hline Moral & $\underline{a}$ & Property & & Social & ש & Communities & & Caste & $E$ \\
\hline Psychological & 已 & Land Rights & & & & & & Occupation & 흐 \\
\hline & & Chauvinism & & & & & & & \\
\hline & & Patriarchy & & & & & & & \\
\hline & & Scapegoating & & & & & & & \\
\hline
\end{tabular}

Figure 1. Ontology of Practice of Witch-Hunting in Assam

Source: Author's Own Compilation

The impact on the perpetrated can be affected by acts embedded in these pathways. For example:

- Social impact of property based physical acts of family's perpetrators perpetrated on the income of the victims.

- Moral impact of patriarchy based social acts of individual perpetrators perpetrated on the caste of the victims.

- Psychological impact of scapegoating based psychological acts of communities' perpetrators perpetrated on the sex of the victims.

- Economic impact of land rights based physical acts of individual perpetrators perpetrated on the occupation of the victims.

\section{Analysis of Ontology}

The focus of the study is on the impact of the witch-hunt and the main purpose is to study the problem by looking at the different factors of witch-hunting which leads to different acts by families, individuals, and communities and the types of outcomes. The ontology of witch hunt attempts to provide a lens for a comprehensive depiction of the issue in the top-down approach. There are four types of impact on the perpetrated i.e. social, psychological, moral, and economical. The social and economic impact is when the victim is exiled from society or denied their rights to the property. While the moral and psychological impact is when the victim is secluded from society or is given a silent treatment by society (Yasmin, 2018). The acts of these groups can affect the sex of the victims, age of the victim, the caste of the victim, and economic status of the victim.

There are three types of perpetrators on four types of perpetrated. The acts that are perpetrated on the victims are physical, psychological, and social. The physical acts involve physical assault when a victim is beaten up by the individual or lynched by the community or family. The psychological act involves when a victim is called by names like daini or witch and she is being assaulted mentally by her family or any close individual. The social act of perpetuation involves when the victim is excluded from society or when the woman is asked to leave her community and village. Also, when she is denied excess to community property like well, paddy fields or temple (Rai, 2020)

And the motivation or the factors for perpetrating witch hunt can be revenge based, property dispute, male chauvinism or patriarchy, sexual orientation, or scapegoating. Revenge based physical act is perpetrated by an individual when he or she serves its interest. Likewise, a scapegoating based psychological act is perpetrated by 
communities on the sex of the victim because the victim is blamed for all the wrongdoing or blames for all the negative things in her surroundings. The victim can be blamed for illness or diseases to her family or neighbors, dying of the cattle in their neighborhood or failure in crop cultivation during the harvest seasons (Islam \& Ahmed, 2017).

The perpetrators need not always be an individual as witch-hunting is a community act (Borah \& Das, 2019). When the communities perpetrated the victims can be excluded from the society, where else when a family perpetrates it can lead to exclusion of the victim from the family. Also, when an individual perpetrates it is easier to manage and convict the culprit, however, when a community perpetrates it becomes more challenging. Physical acts are easier to prosecute than the psychological act. The psychological acts are discreet in nature. Victims may suffer silently, and the victim may fail to provide evidence that she is hunted or abused on the grounds of witch hunt.

\section{Discussion}

An accusation of witchcraft is triggered by a situation that spurs the instigators in some ways. In most cases of witch-hunt, the trigger is illness or death of a human. The victims were held responsible for an alleged illness (ranging from wounds and infection, mental illness, stomach aches, diarrhea, fever, tuberculosis, jaundice, etc.), inability to conceive a child or birth of still-born babies, deaths due to illness or even death of victim's own children (Masoodi, 2014). The accusations become even more plausible in contexts where the victims share physical proximity with the perpetrator. Also, extreme religiosity, difference in religious practice, any novel ritual practice etc. are themselves read as a sign of witchcraft and may be treated as evidence to support the labelling. Jealousy, animosity, and conflict also, triggers witch-hunt. Often, random events such as repeated bad dreams, death on account of an undiagnosed illness a few days after a feast offered by the victim or sometimes a simple visit by the victim seem to triggered accusations, especially where pre-existing conflict, tension, animosity or jealousy is evident (PLD, 2013). This accusation may be intentional orchestrated. It is also indicated that witch accusations are sometimes used to settle scores and at other times it may appears that belief in superstitions fuels suspicion against someone with whom animosity in the broader sense already exists. Upon the allegation of witch-hunting, women are forced in exile from the society or in worst cases have to face brutal punishment (Neogi, 2019). In 2015, a special law was brought in Assam to criminalized witch-hunting. Assam Witch Hunting (Prohibition, Prevention and Protection) Act, 2015 and the key features of this law are that it aims to eradicate superstitions from society by making such crimes non-bailable and non-compoundable. This provision comes under punishment for murder of Indian Penal Code (IPC) if someone is killed after being branded a witch. The law prohibits any person from calling, identifying or defaming any other person as witch by words, sign, conducts or indications. The law prescribes severe punishment if anybody found guilty. It enforces up to 7 years of jail and fine up to 5 lakh rupees (Rahman, 2018).

\section{Women as Witches}

Women are the prime targets of witch-hunting. It is specific to elderly women per say they can be women of any age especially 20 years and above are prime targets but also for them to be targeted they need to be weak and vulnerable (Marshall, 2019). It is interesting to note that the anecdotes were cases of only women being branded as witches. In the event of witch hunt murder narratives, all the victims were women. The treatment and sanctions in the case of witch-hunting are very brutal and inhuman treatment (Müller \& Sanderson, 2020). Here one could justify the argument by taking into account the larger picture of the patriarchal structure of Indian society in general and situate the secondary status of women in this context (Parpart et al., 2000). Holistically, this in turn could explain the consistent incidents of violence against women.

\section{Witch hunt: The actual and speculative reasoning}

Specifically speaking the reasons associated with witch hunt can be categorized into two types: the actual and the speculative (Shaffer, 2014). This can be better explained with an illustration (Banerjee, 2017): A woman (in 
one of the case studies) was branded as a witch and was eventually tortured by her stepson. The actual reason behind this witch hunt practice was the property issues. The stepmother had most of the land to her name and the son could not buy this reality, his greed, jealousy, and materialistic needs forced him to kill his mother. But the speculative reason (justification given to the public) was "she is a witch" and was responsible for his son's illness; this was further sanctioned by the community on the declaration made by the Ojha/Janguru. The main reasons that have come out are property issues, jealousies and sibling rivalries associated with it (as mentioned above), rejection in love (one boy tortured the girl he loved because she rejected him and got engaged to someone else, he branded her as a witch), rejection of sexual advances (one woman was branded as a witch because she declined a sexual gesture of an influential village person,) inter tribe or outside tribe marriages/love affairs (a tribal woman married a Brahmin man and the villagers branded her as a witch), when a tribal family attains economic prosperity (an old man and his family were branded as witches when he made some profit from his business. It is believed equal wealth in tribal communities is essential. The old women had grown wealthy so he was envied and was accused of "eating" others' wealth in the village) and personal grudge (which can be diverse and may include all the above reasons and more). These reasons are unique to this research and in addition to the conventional causes this study brings out some less talked about explanations used to justify such actions of violence. Such actions of violence benefit the accuser groups as they attain personal satisfaction. Most of them have no regrets in committing such crimes and they continue to sustain such beliefs.

\section{Suggestion}

The new Act is a positive step for society to tackle the witch-hunting menace. But the solution of witch-hunting problem lies in the active participation of all the stakeholders of society. One of the most important stakeholders is the police force. The rural people feared they would be abandoned by the community and villages. The situation is so bad that the family members of the victims wouldn't come forward to report. In cases of witch hunt, $95 \%$ of the victims are woman. And there have been many cases where the victim has refused to approach the police because they are male, and the victims are uncomfortable in discussing their physically assault in front of a male police officer. Therefore, this is one of the many reasons that the cases of witch hunt are not registered. Under the Assam Police Act, 2007 Special Woman Police Task force can be set up in most affected areas of witch hunt to address the issue. The police force can be vested with the power to act immediately once the complaint is registered. Also, deploying Women Police patrol vehicle along with helpline number by government will also help.

\section{Limitation}

Witch-Hunting is a sensitive topic and people are apprehensive to talk about the issue. Given the fact that most of the cases of witch-hunting takes place in rural area and in close community. It is difficult to get the actual data on witch-hunting. Also, most of the cases are not reported. There is a problem of under-reporting, therefore it is difficult to get the actual number of cases, how many cases are reported, and action taken against the perpetrator.

\section{Conclusion}

The ontology serves as a cognitive map to systematically and symmetrically analyze the problem based on anecdotal evidence. This research paper highlights witch-beliefs and witch-hunts inter-linkages and some of the reasons for their existence in the first place. Witch beliefs and witch-hunting are not specific to the Indian society and it will be rather problematic to say that it is something specific to the tribal communities. But the instances of witch-hunting can be located mostly among the tribal folks. We cannot completely blame it on the lack of education or bad health care systems. It is deeply ingrained in the patriarchal structure characterized by neoliberalism. Thus, to conclude, it can be put forth that the criminalization of witch hunt is the only aspect of justice. Awareness programs are often a long-term solution for witch-hunting and creating of scientific rationality among the tribal folks or their communities. Eradication of witch-hunting is still a distant dream until 
and unless there is a change in the thought process along with scientific attention is paid to the institutional mechanisms.

\section{References}

Banerjee, B. (2017). Witch Beliefs and Violence Against Women Among Tribal Communities in West Bengal [Master of Arts, Tata Institute of Social https://www.researchgate.net/publication/318653799_Witch_Beliefs_and_Violence_Against_Women_Among_ Tribal_Communities_in_West_Bengal

Beal, V. (2020). Definition of Bolean Search. https://www.webopedia.com/TERM/B/Boolean_search.html

Behera, A. K. (2015, September 19). Greed for property and power behind Jharkhand witch hunts. Hindustan Times. $\quad$ https://www.hindustantimes.com/analysis/greed-for-property-and-power-behind-jharkhand-witchhunts/story-0bXbC7570p8hjk4eNjsipK.html

Bever, E. (2002). Witchcraft, Female Aggression, and Power in the Early Modern Community. Journal of Social History, 35(4), 955-988. JSTOR.

Borah, L., \& Das, M. (2019). Witch-Hunting in Assam: Myth or Reality. Space and Culture, India, 7(3), 99. https://doi.org/10.20896/saci.v7i3.566

Cameron, J. D., Ramaprasad, A., \& Syn, T. (2017). An Ontology of and Roadmap for mHealth Research. International Journal of Medical Informatics, 100, 16-25. https://doi.org/10.1016/j.ijmedinf.2017.01.007

Chandrasekaran, B., Josephson, J. R., \& Benjamins, V. R. (1999). What Are Ontologies, and Why Do We Need Them? IEEE Intelligent Systems, 14(1), 20-26. https://doi.org/10.1109/5254.747902

Chaudhuri, S. (2012). Women as Easy Scapegoats: Witchcraft Accusations and Women as Targets in Tea Plantations of India. Violence Against Women, 18(10). https://doi.org/10.1177/1077801212465155

Cimino, J. J. (2006). In defense of the Desiderata. Journal of Biomedical Informatics, 39(3), $299-306$. https://doi.org/10.1016/j.jbi.2005.11.008

Gruber, T. R. (1995). Toward Principles for the Design of Ontologies Used for Knowledge Sharing. International Journal Human-Computer Studies, 43(5-6), 907-928. https://doi.org/10.1006/ijhc.1995.1081

Gruber, T. R. (2008). Ontology. In L. Liu \& M. T. Özsu (Eds.), Encyclopedia of Database Systems. SpringerVerlag.

Iqbal, M. T. (2015). WITCH HUNTING: A CASE OF GENDER VIOLENCE IN THE GARB OF VIGILANTISM IN INDIA. International Journal of Advanced Research in Management and Social Sciences, 4(11), 12.

Islam, J., \& Ahmed, A. (2017). Witch Hunting in Assam: Practices, causes, legal issues and challenges. Unitedworld Law Journal, 1(II), 135-145.

Krantz, G., \& Garcia-Moreno, C. (2005). Violence against women. Journal of Epidemiology \& Community Health, 59(10), 818-821. https://doi.org/10.1136/jech.2004.022756

Mahanta, U. (2017, September 19). Witch-hunting: A social ill law alone cannot fight. Deccan Herald. https://www.deccanherald.com/content/633929/witch-hunting-social-ill-law.html

Marshall, B. (2019, October 23). Most witches are women, because witch hunts were all about persecuting the powerless. The Conversation. http://theconversation.com/most-witches-are-women-because-witch-hunts-wereall-about-persecuting-the-powerless-125427

Masoodi, A. (2014). Witch hunting | Victims of $\quad$ superstition. Mint. https://www.livemint.com/Politics/Nnluhl4wjhiAAUklQwDtOL/Witch-hunting--Victims-of-superstition.html

McCoy, T. (2014). Thousands of women, accused of sorcery, tortured and executed in Indian witch hunts-The Washington Post. The Washington Post. https://www.washingtonpost.com/news/morningmix/wp/2014/07/21/thousands-of-women-accused-of-sorcery-tortured-and-executed-in-indian-witch-hunts/

Medhi, R. (2016). Witch Hunting in Assam: An Overview. Third Concept, 30, 23-29.

Mehra, M., \& Agrawal, A. (2016). 'Witch-hunting' in India? Economic \& Political Weekly, 13, 7.

Müller, C., \& Sanderson, S. (2020, January 10). Witch hunts: A global problem in the 21st century | DW | 10.08.2020. DW.COM. https://www.dw.com/en/witch-hunts-a-global-problem-in-the-21st-century/a-54495289 
Neogi, D. (2019). To Study the Practice of itch-Hunting in Assam, An Ontology [Mount Carmel College, Autonomous]. https://doi.org/10.13140/RG.2.2.21522.20165

Niaz, U. (2003). Violence against Women in South Asia. ResearchGate, 6(3)(173-84). Archives of Women s Mental Health. https://doi.org/10.1007/s00737-003-0171-9

Parpart, J. L., Connelly, M. P., \& Barriteau, V. E. (2000). Theoretical Perspectives on Gender and Development. nternational Development Research Centre. https://www.idrc.ca/sites/default/files/openebooks/272-4/index.html

PLD. (2013). Piecing Together Perspectives on Witch Hunting: A Review of Literature (SSRN Scholarly Paper ID 2660710). Social Science Research Network. https://doi.org/10.2139/ssrn.2660710

Rahman, J. (2018). Witch Hunting (Prohibition, Prevention and Protection) Bill, 2015. Daily Current Affairs. https://abhipedia.abhimanu.com/Article/State/MjYyMwEEQQVVEEQQVV/Witch-Hunting--Prohibition-Prevention-and-Protection--Bill--2015-Assam-State

Rai, D. (2020, January 29). Atrocious Witch Hunting Attacks in India: Need for Central legislation. IPleaders. https://blog.ipleaders.in/witch-hunting-attacks-in-india/

Ramaprasad, A. (1982). Revolutionary Change and Strategic Management. Behavioral Science, 27(4), 387-392.

Ramaprasad, A. (1983). On the Definition of Feedback. Behavioral Science, 28(1), 4-13.

Ramaprasad, A. (1987). Cognitive Process as a Basis for MIS and DSS Design. Management Science, 33(2), 139-148.

Ramaprasad, A., \& Mitroff, I. I. (1984). On Formulating Strategic Problems. Academy of Management Review, 9(4), 597-605.

Ramaprasad, A., \& Poon, E. (1985). A Computerized Interactive Technique for Mapping Influence Diagrams (MIND). Strategic Management Journal, 6(4), 377-392. JSTOR.

Ramaprasad, A., \& Syn, T. (2015). Ontological Meta-Analysis and Synthesis. Communications of the Association for Information Systems, 37(7), 138-153.

Sadual, M. K. (2015). Modern Day Witch Hunting in India: Socio-Legal Perspectives. Asian Journal of Research in Social Sciences and Humanities, 5(7), 43. https://doi.org/10.5958/2249-7315.2015.00158.6

Shaffer, R. (2014, August). Modern Witch Hunting and Superstitious Murder in India | Skeptical Inquirer. Science and Religion, 38. https://skepticalinquirer.org/2014/07/modern-witch-hunting-and-superstitious-murderin-indial

Shakti, B. S. (2017). Tackling Violence Against Women: A Study of State Intervention Measures. 357.

Simon, H. A. (1962). The Architecture of Complexity. Proceedings of the American Philosophical Society, 106(6), 467-482.

WHO. (2013). Violence against women: A 'global health problem of epidemic proportions.' WHO; World Health Organization. https://www.who.int/mediacentre/news/releases/2013/violence against_women_20130620/en/

WHO. (2017). Violence against women. https://www.who.int/news-room/fact-sheets/detail/violence-againstwomen

Yasmin, S. (2018, January 11). Witch Hunts Today: Abuse of Women, Superstition and Murder Collide in India-Scientific American. Scientific American. https://www.scientificamerican.com/article/witch-huntstoday-abuse-of-women-superstition-and-murder-collide-in-india/

Yogesh, A., \& Kosambi, M. (1993). Violence against women: Reports from India and the Republic of Korea. UNESCO Principal Regional Office for Asia and the Pacific. https://unesdoc.unesco.org/ark:/48223/pf0000096629 